\title{
ANTHROPOGENIC ${ }^{14} \mathrm{C}$ VARIATIONS IN ATMOSPHERIC $\mathrm{CO}_{2}$ AND WINES
}

\author{
A A BURCHULADZE*, MARTIN CHUDÝ**, I V ERISTAVI* \\ S V PAGAVA*, PAVEL POVINEC**, ALEXANDER ŠIVO** \\ and G I TOGONIDZE*
}

\begin{abstract}
As an extension of the Bratislava - Tbilisi collaboration, thermonuclear bombproduced ${ }^{14} \mathrm{C}$ variations in atmospheric $\mathrm{CO}_{2}$ of Bratislava (1967-1987) and in annually produced Georgian wines $(1950-1987)$ are discussed. ${ }^{14} \mathrm{C}$ produced in bomb tests performed in the atmosphere has considerably modified the natural ${ }^{14} \mathrm{C}$ levels in the atmosphere and biosphere. Measurements of ${ }^{14} \mathrm{C}$ in monthly samples of atmospheric $\mathrm{CO}_{2}$ show typical seasonal variations with maxima in summers and deep minima in winters. There is very good agreement between ${ }^{14} \mathrm{C}$ measured in $\mathrm{CO}_{2}$ and in wine samples. Four maxima $(1959,1964,1970$ and 1978) were identified in the wine data. Our results confirm that wines prepared from annually grown grapes without any addition of other substances are good indicators of the ${ }^{14} \mathrm{C}$ content of atmospheric $\mathrm{CO}_{2}$.
\end{abstract}

\section{INTRODUCTION}

Thermonuclear weapon tests performed in the atmosphere have considerably modified the natural ${ }^{14} \mathrm{C}$ concentration in the environment. Large tests performed in 1961 and 1962 increased the ${ }^{14} \mathrm{C}$ concentration in the north atmosphere in 1963 to ca $100 \%$ above the natural level (Nydal \& Lövseth, 1965). Radioactive clouds reached the upper troposphere and lower stratosphere, and due to the specific mixing processes in the atmosphere, seasonal variations of ${ }^{14} \mathrm{C}$ concentration in the troposphere have been observed (Münnich, 1963; Nydal \& Lövseth, 1965; Chudý et al, 1970). After the nuclear moratorium for atmospheric tests in $1963,{ }^{14} \mathrm{C}$ excess has been decreasing with small interruptions caused by subsequent nuclear tests (Povinec, Chudý \& Šeliga, 1971; Levin, Münnich \& Weiss, 1980; Povinec, Chudý \& Šivo, 1986).

Bomb-produced ${ }^{14} \mathrm{C}$ has considerably influenced ${ }^{14} \mathrm{C}$ concentration in the environment. Present levels in the atmosphere are still ca $15 \%$ above natural ${ }^{14} \mathrm{C}$ concentration. The distribution of carbon in the environment has been traced using anthropogenic ${ }^{14} \mathrm{CO}_{2}$. This enables us to study exchange processes among various carbon reservoirs in the atmosphere, biosphere and ocean, and to estimate transport coefficients (Oeschger $e t a l$, 1975).

Investigations of this kind are important for understanding natural variations of ${ }^{14} \mathrm{C}$ in the environment. Except for long-term variations, which are difficult to study (Stuiver, 1978), these investigations are important also for short-term ${ }^{14} \mathrm{C}$ variations studies (eg, $11-y r$ solar ${ }^{14} \mathrm{C}$ cycle), which have very small amplitudes (Povinec, Burchuladze \& Pagava, 1983).

From this point of view, studies of the correlation between ${ }^{14} \mathrm{C}$ concentration in the atmosphere and in annually dated samples (eg, tree rings, wine, etc) are very important. Wines prepared from annually grown grapes

\footnotetext{
${ }^{*}$ Tbilisi State University, Faculty of Physics, Department of Nuclear Physics, 380028 Tbilisi, USSR

** Comenius University, Faculty of Mathematics and Physics, Department of Nuclear Physics, 84215 Bratislava, Czechoslovakia
} 
without any addition of substances should represent the average ${ }^{14} \mathrm{C}$ content of the atmosphere during the time of growth of the grapes. Annual wines represent a year-by-year record that goes back to the beginning of this century. Together with tree rings that date back several thousand years, wines enable us to study, with high precision, ${ }^{14} \mathrm{C}$ variations in the atmosphere. Careful investigation has shown $11-\mathrm{yr}{ }^{14} \mathrm{C}$ variations in wine over four solar cycles (Burchuladze et al, 1980). Another possibility is to study annually prepared whiskies (Baxter, Ergin \& Walton, 1969).

This work is a continuation of the Bratislava-Tbilisi collaboration on short-term variations of ${ }^{14} \mathrm{C}$ in annual Georgian wine samples (Burchuladze et al, 1977; Burchuladze et al, 1980; Povinec, Burchuladze \& Pagava, 1983) with emphasis on the response of wines to short-term fluctuations ${ }^{19}{ }^{14} \mathrm{C}$ concentration in the atmosphere caused by nuclear bomb tests.

\section{METHODS AND SAMPLES}

\section{Atmospheric $\mathrm{CO}_{2}$ Samples}

Monthly and short-term samples of atmospheric $\mathrm{CO}_{2}$ have been collected at various sites in Slovakia (Bratislava, Jaslovské Bohunice and Modra) since 1967 using the method of static and dynamic absorption of $\mathrm{CO}_{2}$ in $\mathrm{NaOH}$ solution (Povinec et al, 1968) and in molecular sieve Calsit 5A (Povinec, 1975). Up to 1975, Bratislava samples were taken from the center of the town. Later, they were collected on the roof of a new department store on Mlynská dolina, which is in the outskirts. Thus, all samples represent surface air samples.

The $\mathrm{CO}_{2}$ absorbed in $\mathrm{NaOH}$ was precipitated as $\mathrm{BaCO}_{3}$, converted to $\mathrm{CO}_{2}$ by adding $\mathrm{H}_{3} \mathrm{PO}_{4}$ and the $\mathrm{CO}_{2}$ purified to remove electronegative impurities; the sample was counted as $\mathrm{CO}_{2}$ or as $\mathrm{CH}_{4}$ after reduction. Lowlevel proportional counters were used for ${ }^{14} \mathrm{C}$ activity measurements. The methods of ${ }^{14} \mathrm{C}$ sample collection and measurement have been described previously (Povinec et al, 1968; Povinec, 1972; Povinec et al, 1973) and will not be outlined here.

\section{Wine Samples}

Georgian wine samples were collected by the Tbilisi Wine Museum and the Research Institute of Grape-Growing in Tbilisi. The samples were stored separately in bottles for each year. They were well preserved, which was already documented by dating wine samples from the beginning of this century (Burchuladze et al, 1980). No admixtures (eg, sugar, artificial ingredients) were added to the samples.

The samples were distilled, and the condensed ethyl alcohol was burned in a high-pressure combustion bomb to form $\mathrm{CO}_{2}$ that was used for preparation of benzene. Intertechnique SL-20 and SL-30 liquid scintillation spectrometers were used for ${ }^{14} \mathrm{C}$ counting. This technique was described previously (Povinec et al, 1980; Burchuladze et al, 1980). Several crosscheck measurements between the Bratislava and Tbilisi laboratories have shown results within statistical errors. 


\section{RESULTS AND DISCUSSION}

Figure 1 shows a comparison of the ${ }^{14} \mathrm{C}$ concentration in Georgian wine samples with the ${ }^{14} \mathrm{C}$ concentration of monthly sampled Bratislava $\mathrm{CO}_{2}$. Wine samples from different Georgian villages $\left(\sim 38^{\circ} \mathrm{N}, \sim 45^{\circ} \mathrm{E}\right)$ from 1950-1987 are listed in Table 1. The wine samples were collected in nonindustrial areas; thus, they can be expected to produce "clean-air" data. However, some local influences from nearby villages cannot be excluded. The ${ }^{14} \mathrm{C}$ record in Bratislava $\left(\sim 48^{\circ} \mathrm{N}, \sim 17^{\circ} \mathrm{E}\right) \mathrm{CO}_{2}$ is given from 1967-1987 (Povinec et al, 1986).

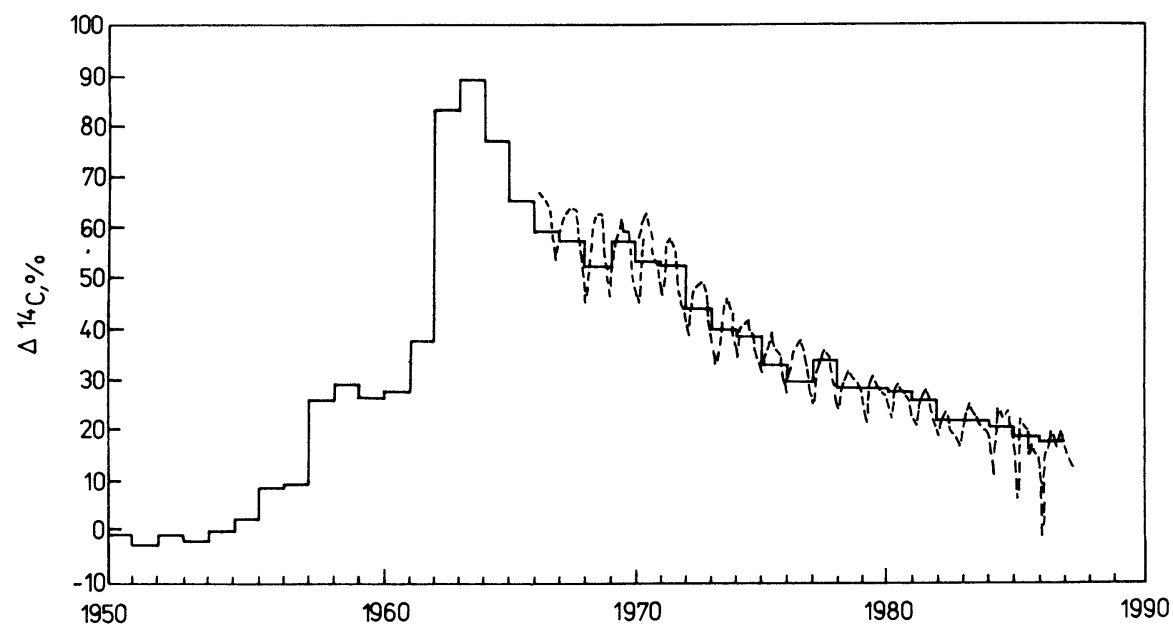

Fig 1 . Thermonuclear bomb-produced ${ }^{14} \mathrm{C}$ variations in samples of annually produced Georgian wines $\left(\sim 38^{\circ}\right.$ $\left.\mathrm{N}, \sim 45^{\circ} \mathrm{E}\right)$ and in monthly samples of atmospheric $\mathrm{CO}_{2}$ in Bratislava $\left(\sim 48^{\circ} \mathrm{N}, \sim 17^{\circ} \mathrm{E}\right)$

$-=$ wines; $---=\mathrm{CO}_{2}$

We have obtained very good agreement between ${ }^{14} \mathrm{C}$ measured in wine samples and in atmospheric $\mathrm{CO}_{2}$. Although Bratislava atmospheric results cannot be accepted as clean-air data, they predict well, until $1980,{ }^{14} \mathrm{C}$ concentration in wines. After 1980, the influence on atmospheric data of the annual Suess effect, especially during winter, is remarkable. The wine data are systematically higher than the mean annual atmospheric data; this is due not only to the Suess effect, but also to the fact that the growth period of grapes is only ca $10-15$ weeks during the year at a time when the ${ }^{14} \mathrm{C}$ concentration in atmospheric $\mathrm{CO}_{2}$ is around its maximum.

Four maxima can be identified in the wine data. The first, in 1959, is due to nuclear bomb tests during the 1950s. The second, the sharp 1964 maximum, is due to the largest tests in 1961 and 1962, and it corresponds to the maximum observed in atmospheric $\mathrm{CO}_{2}$ in 1963 (Nydal \& Lövseth, 1965). The one-year shift between the atmospheric ${ }^{14} \mathrm{C}$ level and ${ }^{14} \mathrm{C}$ concentration in wine is typical, and it is observed also when two much smaller maxima, due to more recent nuclear bomb tests, are found at 1970 and 1978. After the atmospheric nuclear test moratorium in 1963 , the ${ }^{14} \mathrm{C}$ con- 
TABLE 1

${ }^{14} \mathrm{C}$ content of Georgian wine samples

\begin{tabular}{|c|c|c|}
\hline Growth yr & Sample & $\Delta^{14} \mathrm{C}(\%)$ \\
\hline 1950 & Georgian no. 20 & $-1.42 \pm 0.20$ \\
\hline 1951 & Tsolikauri & $-4.37 \pm 0.24$ \\
\hline 1952 & Tsinandali & $-1.37 \pm 0.36$ \\
\hline 1953 & Khvanchkara & $-2.53 \pm 0.26$ \\
\hline 1954 & Tibaani & $-0.67 \pm 0.36$ \\
\hline 1955 & Mukuzani & $1.66 \pm 0.29$ \\
\hline 1956 & Gurdzhaani & $6.95 \pm 0.42$ \\
\hline 1957 & Tsolikauri & $8.87 \pm 0.42$ \\
\hline 1958 & Teliani & $25.21 \pm 0.43$ \\
\hline 1959 & Tsolikauri & $29.12 \pm 0.42$ \\
\hline 1960 & Tsinandali & $25.71 \pm 0.38$ \\
\hline 1961 & Gurdzhaani & $27.52 \pm 0.34$ \\
\hline 1962 & Tsinandali & $36.52 \pm 0.29$ \\
\hline 1963 & Tsinandali & $82.31 \pm 0.43$ \\
\hline 1964 & Kardanakhi & $89.16 \pm 0.42$ \\
\hline 1965 & Sviri & $76.48 \pm 0.39$ \\
\hline 1966 & Gurdzhaani & $62.68 \pm 0.46$ \\
\hline 1967 & Mukuzani & $59.71 \pm 0.53$ \\
\hline 1968 & Kardanakhi & $55.15 \pm 0.47$ \\
\hline 1969 & Tibaani & $51.03 \pm 0.31$ \\
\hline 1970 & Gurdzhaani & $57.77 \pm 0.32$ \\
\hline 1971 & Tsinandali & $53.40 \pm 0.34$ \\
\hline 1972 & Tibaani & $53.28 \pm 0.32$ \\
\hline 1973 & Tibaani & $42.63 \pm 0.24$ \\
\hline 1974 & Saero & $39.77 \pm 0.28$ \\
\hline 1975 & Tsinandali & $36.80 \pm 0.25$ \\
\hline 1976 & Tsitska & $33.20 \pm 0.29$ \\
\hline 1977 & Telavi & $29.77 \pm 0.26$ \\
\hline 1978 & Rkatsiteli & $34.49 \pm 0.28$ \\
\hline 1979 & Tsinandali & $29.45 \pm 0.24$ \\
\hline 1980 & Tsinandali & $27.93 \pm 0.26$ \\
\hline 1981 & Lechkhumi & $27.15 \pm 0.26$ \\
\hline 1982 & Rkatsiteli & $26.57 \pm 0.24$ \\
\hline 1983 & Telavi & $22.98 \pm 0.25$ \\
\hline 1984 & Tsolikauri & $21.59 \pm 0.25$ \\
\hline 1985 & Lechkumi & $20.87 \pm 0.25$ \\
\hline 1986 & Racha & $18.98 \pm 0.23$ \\
\hline 1987 & Rkatsiteli & $16.79 \pm 0.23$ \\
\hline
\end{tabular}


centration in wines, with these two interruptions, has been decreasing with approximate time constants $6.3 \%$ per year during the $1960 \mathrm{~s}, 3.1 \%$ per year during the $1970 \mathrm{~s}$ and $1.5 \%$ per year during the $1980 \mathrm{~s}$.

Atmospheric ${ }^{14} \mathrm{C}$ data show typical seasonal variations with maxima in summer months which are due to stratospheric injection of fresh air to the troposphere during the spring in the Northern Hemisphere. Deep minima during the winter are due to dilution of ${ }^{14} \mathrm{C}$ concentration by addition of fossil-fuel $\mathrm{CO}_{2}$ (Segl et al, 1983).

\section{CONCLUSION}

${ }^{14} \mathrm{C}$ produced during thermonuclear bomb tests in the atmosphere has considerably modified the natural ${ }^{14} \mathrm{C}$ levels in the atmosphere. The present ${ }^{14} \mathrm{C}$ concentration is still ca $15 \%$ above the natural level, as documented by ${ }^{14} \mathrm{C}$ measurements in atmospheric $\mathrm{CO}_{2}$ and in recent wines. Monthly sampled atmospheric $\mathrm{CO}_{2}$ shows typical seasonal ${ }^{14} \mathrm{C}$ variations with maxima in summer and deep minima in winter.

The present study has confirmed that wines prepared from annually grown grapes without any addition of other substances are good indicators of the ${ }^{14} \mathrm{C}$ content of atmospheric $\mathrm{CO}_{2}$. They represent a year-by-year record that dates back to the beginning of this century. Together with tree rings that date back several thousand years, wine samples enable us to investigate, with high precision, ${ }^{14} \mathrm{C}$ variations in the atmosphere.

\section{ACKNOWLEDGMENTS}

We thank the management of the Tbilisi Wine Museum and the Research Institute of Grape-Growing in Tbilisi for providing us with the wine samples.

\section{REFERENCES}

Baxter, M S, Ergin, M and Walton, A, 1969, Glasgow University radiocarbon measurements I: Radiocarbon, $\mathrm{v} 11$, no. 1, p 43-52.

Burchuladze, A A, Gedevanishvili, D D, Pagava, S V and Togonidze, G I, 1977, Radiocarbon variations in the atmosphere for period 1950-1975 obtained from analysis of wine spirits, in Povinec, $\mathrm{P}$ and Usačev, $\mathrm{S}$, eds, Internatl conf on low radioactivity measurements and applications, Proc: SPN Bratislava, p 261-263.

Burchuladze, A A, Pagava, S V, Povinec, P, Togonidze, G I and Usačev, S, 1980 Radiocarbon variations with the 11-year solar cycle during the last century: Nature, $v 287$, p $320-322$.

Chudý, M, Povinec, P, Šeliga, M and Śáró, S, 1970, Carbon-14 in atmosphere and biosphere: Radioisotopy, v 11, p 935-951.

Levin, I, Münnich, K and Weiss, W, 1980, The effect of anthropogenic $\mathrm{CO}_{2}$ and ${ }^{14} \mathrm{C}$ sources on the dilution of ${ }^{14} \mathrm{C}$ in the atmosphere, in Stuiver, $\mathrm{M}$ and $\mathrm{Kra}, \mathrm{R} \mathrm{S}$, eds, Internatl ${ }^{14} \mathrm{C}$ conf, 10th, Proc: Radiocarbon, v 22, no. 2, p 379-391.

Münnich, K O, 1963, Der Kreislauf des Radiokohlenstoffs in der Natur: Naturwissenschaften, v 6, p 211-218.

Nydal, R and Lövseth, 1965, Distribution of radiocarbon from nuclear tests: Nature, v 206, p $1029-1031$.

Oeschger, H, Siegenthaler, U, Schotterer, U and Gugelmann, A, 1975, A box diffusion model to study the carbon dioxide exchange in nature: Tellus, v 27, p 168-192. 
Povinec, P, 1972, Preparation of methane gas filling for proportional ${ }^{3} \mathrm{H}$ and ${ }^{14} \mathrm{C}$ counter: Radiochem Radioanal Letters, v 9, p 127-135.

- 1975, The analysis of ${ }^{3} \mathrm{H}$ and ${ }^{14} \mathrm{C}$ labelled compounds in the form of doubly labelled methane: Internatl Jour Applied Radiation Isotopes, v 26, p 465-469.

Povinec, P, Burchuladze, A A and Pagava, S V, 1983, Short-term variations in radiocarbon concentration with the 11-year solar cycle, in Stuiver, M and Kra, R S, eds, Internatl ${ }^{14} \mathrm{C}$ conf, 11th, Proc: Radiocarbon, v 25, no. 2, p 259-266.

Povinec, P, Burchuladze, A A, Usačev, S, Pagava, S V, Togonidze, G I, Eristavi, I V, Polášková, A and Šivo, A, 1980, Preparation of counter fillings for high precision radiocarbon measurements: Acta Univ Physica, v 20, p 185-195.

Povinec, P, Chudý, M and Šeliga, M, 1971, Carbon-14 in atmospheric $\mathrm{CO}_{2}$ as a tracer: Acta Univ Comen Physica, v 11, p 91-100.

Povinec, P, Chudý, M and Šivo, A, 1986, Anthropogenic radiocarbon: past, present and future, in Stuiver, M and Kra, R S, eds, Internatl ${ }^{14} \mathrm{C}$ conf, 12th, Proc: Radiocarbon, v 28 , no. $2 \mathrm{~A}, \mathrm{p} 668-672$.

Povinec, P, Sáró, Š, Chudý, M and Šeliga, M, 1968, The rapid method of carbon-14 counting in atmospheric carbon dioxide: Internatl Jour Applied Radiation Isotopes, v 19, p 877-881.

Povinec, P, Sivo, A, Chudý, M, Burchuladze, A A, Pagava, S V, Togonidze, G I and Eristavi, I V, 1986, Seasonal variations of anthropogenic radiocarbon in the atmosphere, in Povinec P, ed, Internatl conf on low level counting, 3rd, Proc: Nuclear Instruments \& Methods, v B17, p 556-559.

Povinec, P, Usačev, S, Chudý, M and Šeliga, M, 1973, Bratislava radiocarbon measurements I: Radiocarbon, v 15 , no. 3, p 443-450.

Segl, M, Levin, I, Schoch-Fischer, H, Münnich, M, Kromer, B, Tschiersch, J and Münnich, K $\mathrm{O}, 1983$, Anthropogenic ${ }^{14} \mathrm{C}$ variations, in Stuiver, $\mathrm{M}$ and Kra, R S, eds, Internatl ${ }^{14} \mathrm{C}$ conf, 11th, Proc: Radiocarbon, v 25, no. 2, p 583-592.

Stuiver, M, 1978, Radiocarbon time scale tested against magnetic and other dating methods: Nature, v 273, p 271-274. 